Original Research

\title{
Self-Care Training Improves the Attitudes and Skills of Caregivers for Children with Physical Disability
}

\author{
Warti Ningsih', Purwanta Purwanta ${ }^{2}$ and Sri Hartini $^{2}$ \\ ${ }^{1}$ Master of Nursing Student, Medical Faculty, Gadjah Mada University, Sleman, Indonesia \\ ${ }^{2}$ Department of Nursing, Medical Faculty, Gadjah Mada University, Sleman, Indonesia
}

\begin{abstract}
Introduction: The physical condition of a child with physical disabilities makes them dependent on others. Carers are the closest to children with physical disability and must have the ability to assist and teach children to do self-care activities. This study was aimed to determine the effect of self-care training on the knowledge, attitudes and skills of caregivers about the care of children with physical disability.
\end{abstract}

Methods: The experiment was pre-experimental with one group pre-test-post-test design. The study was conducted on 23 caregivers who experienced caring of children with physical disability. The research instruments are Knowledge and Attitude of Self Care on Children with Physical Disability Questionnaire and Observation Sheet of Self Care on Children with Physical Disability, which have tested the validity and reliability to measure knowledge and attitude. Skill observation uses a check list with the validity test of expert opinion. Training on self-care using lecture, audiovisual, practice and discussion methods was conducted in two sessions on different days with 120 minutes per session. Data analysis used Paired Sample T-Test with significance level $<0.05$.

Results: Self-care training significantly influenced caregivers' attitude $(p=0.038)$ and skill ( $\mathrm{p}=0.002)$, but training has no effect on caregivers' knowledge $(\mathrm{p}=0.225)$.

Conclusion: Self-care training improved attitudes and skills of caregivers for children with physical disability, but did not affect caregivers' knowledge.

\section{ARTICLE HISTORY}

Received: Aug 23, 2017

Accepted: April 30, 2018

\section{KEYWORDS}

self-care training; caregiver; children with physical disability; knowledge; attitude; skill

\section{CONTACT}

Warti Ningsih

warti_ns@yahoo.com

$\doteq$ Medical Faculty,

Gadjah Mada University,

Sleman, Indonesia

Cite this as: Ningsih, W., Purwanta, P., \& Hartini, S. (2018). Self-Care Training Improves the Attitudes and Skills of Caregivers for Children with Physical Disability. Jurnal Ners, 13(1), 9-17.

doi:http://dx.doi.org/10.20473/in.v13i1.5613

\section{INTRODUCTION}

According to WHO, disability is a limitation or inability to perform an activity in a way that is within the range considered normal for humans, largely due to decreased ability (Barbotte and Chau, 2011). Globally, WHO estimates the number of children with disabilities as about $7-10 \%$ of the total child population. According to 2007 National Statistics Agency data, there are 8.3 million children with disabilities among a child population of nearly 83 million in Indonesia, or about $10 \%$. Based on Social Protection Program Data Collection (Pendataan Program Perlindungan Sosial/PPLS), in 2011 there were 130,572 children with disabilities from poor families, including physically disabled children (32,990 children); children with hearing impairment, speech disorder and physically disabled $(4,242$ children); and children with hearing impairment, speech disorder, blind, and physically disabled $(2,991$ children). The data are spread across Indonesia with the highest proportion in Central Java, East Java, and West Java (Riskesdas, 2013). Infants and children with physical disabilities such as cerebral palsy always show difficulty in performing daily activities. This is related to their difficulty to move and positioning their body similar to the limitations in other neurological damage (Chung, et al., 2008). Difficulties often faced by children in routine activities include bathing, morning activities (using cutlery at breakfast, wearing clothes and school supplies, or leaving for school on their own), afternoon activities (changing clothes and doing school work), meal time, play, leaving the house, gathering with family, physical activity and recreation (Kling, et al, 2010). 
Schools for children with physical disabilities (YPAC) in Surakarta are classified into two divisions, that is the SLB D for physically disabled children and SLB D-1 for the physically and mentally disabled children. The mental condition of children was determined by a team of psychologists who had worked with YPAC. The divisions were made because the ability to learn in children with mental disabilities is different from those who only experience physical disabilities.

According to interview data conducted on 12 parents, parents did not know how to teach their children to take care of themselves and had never attended training about it. They said they only found out about it from friends, relatives, therapists and by reading. Parents also said children needed more help in eating, dressing, bathing, toileting and they couldn't bear to see their child's condition. So, even though they felt tired, they tried to enjoy it. Based on observation, there were five children who had uncleaned teeth, five children had dirty hair, four children were sweaty, not tidy and had body odor among 10 children with physical disability.

Education is a combination of learning experiences designed to help individuals and communities in improving their health through increased knowledge or influencing their attitudes and behaviors (WHO, 2015). In Heubner and Milgrom's (2014) study, which was conducted by providing parental training consisting of the provision of materials related to the importance of toothbrushes, practices and discussions for 90 minutes, there were significant changes before and after intervention in the self-confidence, attitude and self-efficacy of parents. This study also showed that the training of parents improved their caring ability, which would be good for the children.

This study was aimed to determine the effect of self-care training on the knowledge, attitudes and skills of caregivers about the care of children with physical disability.

\section{MATERIALS AND METHODS}

The research was held at the Foundation of YPAC Surakarta. It was chosen because YPAC Surakarta is the only foundation that runs an Exceptional School for Physical Disabilities (SLB D) where parents have little knowledge about child self-care with physical disability and no training on self-care. The study was held from March to April 2017 and consisted of pretest from 13 until 26 March, 2017, intervention from 29 until 30 March, 2017, and post-test from 17 until 30 April, 2017.

The population in this research is 26 parents with physically disabled children without mental disorder, limited to children with moderate and light physical disability. The sample is caregivers who attend full sessions, including pre-test, intervention and posttest. Criteria selection of disability level was based on the classification of social service provisions. The sampling technique in this research was determined by total sampling technique. The study was a preexperimental with a one group pre-test-post-test design without control group. The sample is 23 caregivers. There are three caregivers who were excluded from this study because they refused to be respondents, could not attend the intervention session or the intervention sessions were attended by two different caregivers for the same child on different days.

Research interventions are self-care training for caregivers with physically disabled children by providing materials, videos, demonstration and discussion. The pre-test was conducted within two weeks, followed by two sessions of intervention which consisted of 120 minutes per session on different days. The questionnaire was given directly after a full session of intervention.

The material given in the first session of intervention was about self-grooming, dressing and eating and, in the second session of intervention, for bathing and toileting. For effectiveness, respondents were divided into two groups consisted of 13 and 11 caregivers based on the agreement of the time chosen by the respondents. Material was provided by a certified trainer as a speaker and a perception equation was held beforehand between speaker and researcher.

The training was conducted for two sessions with 120 minutes per session. The session consisted of 30 minutes of material provision by the trainer, 15 minutes video presentation, 45 minutes independent practice and 30 minutes discussion.

The data collection was assisted by research assistants. Interclass correlation coefficient was used as inter-rater reliability of 12 observers. The average agreement between raters is 0.998 , which means a very good accuracy on assessment object, and the consistency of a rater is 0.972 , which means that the rater is very consistent in the assessment of the assessed object.

The data collection instrument is Knowledge and Attitude of Self Care on Children with Physical Disability Questionnaire, which has been tested for validity and reliability. There are 18 questions for the assessment of knowledge and 20 statements for a valid attitude assessment with a reliability value of 0.673 and 0.818 , respectively. The skill was assessed by Observation Sheet of Self Care on Children with Physical Disability which has been tested for validity by expert opinion, and observation by 12 raters that has been tested for reliability with intraclass correlation coefficients (ICC) by observing five similar objects. The statistical test result achieved average agreement inter-rater of 0.998 while for an individual rater the consistency is 0.972 .

Prior to the research, research assistants collected the pre-test data using questionnaire by going to the respondent's house to assess the knowledge and attitudes of how to teach self-care in children. The caregivers' skills data were collected by observing the skills of how to teach self-care in children with physical disability. Two weeks after intervention, 
post-test data was collected with a home visit by a different research assistant.

The effect of self-care training on caregivers' knowledge, attitudes and skills on self-care was analyzed using mean values between pre-test, posttest and standard deviation. The normality test was held by using Shapiro Wilk with the result of knowledge and attitude, and skill scores being 0.784 , 0.478 and 0.417 , respectively. It is concluded from the values that all data are normally distributed because of the significance value $>0.05$. The data were analyzed using Paired Sample T Test to determine the effect of self-care training on caregivers' knowledge, attitude and skill with confidence level 95\%.

\section{RESULTS}

Characteristics of respondents consisted of child demographic data and caregiver demographic data, showing that more than half the children were boys (52.17\%), aged $11-15$ years (56.6\%) with average age of 10.18 years with standard deviation 2.07. Most of the children were in Grade 2 (26.9\%) and had moderate disabilities categories with $73.91 \%$. Most of the caregivers were female of whom mothers of the children accounted for $78.26 \%$ and more than half had senior high school as educational level (56.51\%). Almost half of the respondents were aged 31-40 (47.83\%) with average age 41.4 years and most of them were housewives (69.57\%). Based on information and participation in training on self-care of children with physical disability, more than half (69.57\%) had not received information about children's physical disability care before and $82.61 \%$ had never attended self-care training.

The description of knowledge, attitude and skill was determined by a cutoff point using normative value that is the mean of pre-test because the data were normally distributed. Based on Table 2, almost half of the caregivers had good knowledge before training (47.8\%) and this increased after training $(69.6 \%)$. The caregivers' attitudes increased from $56.5 \%$ to $82.6 \%$ after training as well as the skills, which increased from $43.5 \%$ to $95.7 \%$.

The characteristics of caregivers including sex, education level, occupation and relationship with children, had no effect on knowledge, attitude and skill of caregivers after receiving self-care training on children with physical disability (Table 3 ).

Based on Table 4, there are four questions items that had decreased score after the training; the declining scores were on the questions about definition of self-care, bath stages, taught during toileting and toileting tools. There are two item questions that were answered correctly before and after training, which are about equipment for bathing and tools for dressing and dressing.

Based on Table 5, there are 10 item statements that were $100 \%$ answered agree after training, namely, the statement about baths must be with running water, using soap on the whole body, introducing shirt front and back, praising the child if possible, using the bathroom for toileting, teaching handwashing with soap after toileting, holding a spoon and trying other ways while eating, providing light cutlery during exercise, and teaching to chew food before swallowing.

There are some item statements which did not change after self-care training; the attitude of bathing without using soap, teaching children how to clean after toileting, teaching children to drink with a straw, and providing a special table for children. Other attitudes increased after training.

Almost all of the caregivers' skills increased after self-care training. The only skill decrease after self-care training was the skill about teaching children how to choose clothes. There are some skills that previously only few caregivers had which all subsequently acquired (100\%): the skills of teaching to dry the body after bathing, undressing, cleaning after toileting, exiting the bathroom, washing hands after bowing, mouth, holding and drinking from the cup, and wearing the upper garment. The description of skills performed by the caregivers of children with physical disabilities before and after self-care training is shown in Table 6.

The effectiveness of the training process based on the respondents' responses is shown in Table 7. The results of the evaluation of the training process showed no respondents who rated very less or less in the training process. The results showed the training time is sufficient (13.1\%), mostly judging both in terms of training facilities and training time with $78.3 \%$, and more than half rated very good on training benefits with $60.9 \%$. The effects of self-care training on knowledge, attitudes and skills were analyzed by paired sample t test.

Based on Table 8, the effect of self-care training on the knowledge, attitudes and skills of the caregiver by using paired sample $t$ test showed that the training had an effect on the attitude and skill of the caregiver with respective values of ( $p$ 0.038) and ( $p$ 0.002) with $95 \%$ significance level. The training did not affect the caregivers' knowledge ( $p$ 0.225) although there was a slight increase in mean value with differentiation of 0.826 where $t$ counts showed 1.249 smaller than $t$ table, which means self-care training had no effect on caregivers' knowledge.

\section{DISCUSSION}

The study discussion describes the effect of self-care training on the response of physically disabled children's caregivers in training, knowledge, attitudes and skills. The discussion further reviews the correlation between the assessment's aspects with respondents' characteristics and analyzes supporting factors to determine the research intervention's effectiveness.

Almost half $(47.8 \%)$ of caregivers' knowledge before and after physical disability children's selfcare training is good, and the knowledge increased in the majority (69.6\%) of caregivers after training. The 
Table 1. Distribution of Respondents of Children and Caregivers Meeting the Research Criteria at YPAC Surakarta March-April $2017(n=23)$

\begin{tabular}{|c|c|c|c|c|c|c|}
\hline \multirow{2}{*}{ Category } & \multicolumn{3}{|c|}{ Child } & \multicolumn{3}{|c|}{ Caregivers } \\
\hline & $\mathbf{f}$ & $\%$ & Mean (SD) & $\mathbf{f}$ & $\%$ & Mean (SD) \\
\hline \multicolumn{7}{|l|}{ Sex } \\
\hline Male & 12 & 52.17 & & 3 & 13.04 & \\
\hline Female & 11 & 47.83 & & 20 & 86.96 & \\
\hline \multicolumn{7}{|l|}{ Ages } \\
\hline 6-10 year & 10 & 43.5 & $10.87(2.07)$ & & & \\
\hline 11-15 year & 13 & 56.5 & & & & \\
\hline \multicolumn{7}{|l|}{ 16-20 year } \\
\hline 21-30 year & & & & 1 & 4.35 & \\
\hline $31-40$ year & & & & 11 & 47.83 & $41.43(7.54)$ \\
\hline 41-50 year & & & & 9 & 39.13 & \\
\hline$>50$ year & & & & 2 & 8.71 & \\
\hline \multicolumn{7}{|l|}{ Class } \\
\hline I & 5 & 21.74 & & & & \\
\hline II & 6 & 26.09 & & & & \\
\hline III & 4 & 17.39 & & & & \\
\hline IV & 3 & 13.04 & & & & \\
\hline $\mathrm{V}$ & 4 & 17.39 & & & & \\
\hline VI & 1 & 4.35 & & & & \\
\hline \multicolumn{7}{|l|}{ Disabilities Categories } \\
\hline Moderate & 17 & 73.91 & & & & \\
\hline Mild & 6 & 26.09 & & & & \\
\hline \multicolumn{7}{|l|}{ Level of education } \\
\hline Primary School & & & & 5 & 21.74 & \\
\hline Junior High School & & & & 1 & 4.35 & \\
\hline Senior High School & & & & 13 & 56.51 & \\
\hline Diploma & & & & 2 & 8.70 & \\
\hline Bachelor & & & & 2 & 8.70 & \\
\hline \multicolumn{7}{|l|}{ Occupational } \\
\hline House wife & & & & 16 & 69.57 & \\
\hline Private & & & & 3 & 13.04 & \\
\hline Entrepreneur & & & & 4 & 17.39 & \\
\hline \multicolumn{7}{|l|}{ Relation with Children } \\
\hline Mother & & & & 18 & 78.26 & \\
\hline Father & & & & 2 & 8.70 & \\
\hline Grandmother & & & & 2 & 8.70 & \\
\hline Brother & & & & 1 & 4.34 & \\
\hline \multicolumn{7}{|c|}{ Getting information about self-care } \\
\hline Already & & & & 7 & 30.43 & \\
\hline Not, yet & & & & 16 & 69.57 & \\
\hline \multicolumn{7}{|c|}{ Have training about self-care } \\
\hline Ever & & & & 4 & 17.39 & \\
\hline Never & & & & 19 & 82.61 & \\
\hline
\end{tabular}

caregivers' knowledge is good because some $(30.43 \%)$ of them had already obtained information about self-care on physically disabled children from school and other sources. Based on research by Tristani et al. (2017), 70\% of parents have sought to find sources of information about physical activity for children with physical disability through websites using common sources to increase their knowledge.

In a UNICEF study (2014), among 247 mothers, $65 \%$ of mothers had completed their primary education and $81 \%$ of parents with high school education levels had the knowledge and readiness for education of their children at home increased. This is in accordance with research result which finds that the highest education level of caregivers (56.51\%) is Senior High School.

The older the person's age, the better the mental development process, but, at a certain age, the increase in mental development process is not as fast as in their teens. In addition, a person's memory is affected by age. Therefore, the age of a person can affect the acquisition of obtained knowledge, but, at certain ages, the ability to accept or remember will be reduced. The knowledge of 40-year- olds will be different from the current knowledge of 60-year-olds (Notoatmodjo, 2007). The increase in the caregivers' knowledge is less significant because the average age of caregivers is 41.43 years, where $47.83 \%$ are aged 31-40 years.

The decrease of correct answers to some questions on knowledge was also due to the fact that most caregivers (47.83\%) are aged $31-40$ years, at which point there is difficulty in the process of remembering. According to Aizpurua, et al. (2009), the brain is particularly vulnerable in long-term memory processes as age grows. In this study, post- 
Table 2. Distribution of Knowledge Level Description, Attitude and Skills of Caregivers Before and After SelfCare Training $(\mathrm{n}=23)$

\begin{tabular}{lcccc} 
& Variable & \multicolumn{2}{c}{ Before } & \multicolumn{2}{c}{ After } \\
\cline { 2 - 5 } & f & $\%$ & f & $\%$ \\
\hline Knowledge & 11 & 47.8 & 16 & 69.6 \\
Good $\geq 13.17$ & 12 & 52.2 & 7 & 30.4 \\
Less $<13.17$ & 13 & 56.5 & 19 & 82.6 \\
\hline Attitudes & 10 & 43.5 & 4 & 17.4 \\
Positive $\geq 59.57$ & 10 & 43.5 & 22 & 95.7 \\
Negative $<59.57$ & 13 & 56.5 & 1 & 4.3 \\
\hline Skills & & & \\
Good $\geq 26.74$ & & & & \\
\hline
\end{tabular}

Table 3. Analysis of Chi Square Test Characteristics of Child Caregivers with Physical Disability with Knowledge, Attitude and Skills $(\mathrm{n}=23)$

\begin{tabular}{|c|c|c|c|c|c|c|c|c|c|}
\hline \multirow{2}{*}{$\begin{array}{c}\text { Respondents' } \\
\text { Characteristics }\end{array}$} & \multicolumn{3}{|c|}{ Knowledge } & \multicolumn{3}{|c|}{ Attitudes } & \multicolumn{3}{|c|}{ Skills } \\
\hline & $\begin{array}{l}\text { Good } \\
\text { f (\%) }\end{array}$ & $\begin{array}{c}\text { Less } \\
\text { f (\%) }\end{array}$ & $\begin{array}{c}\mathbf{p} \\
\text { value }\end{array}$ & $\begin{array}{c}\text { Positive } \\
\text { f (\%) }\end{array}$ & $\begin{array}{c}\text { Negative } \\
\text { f (\%) }\end{array}$ & $\begin{array}{c}\mathbf{p} \\
\text { value }\end{array}$ & $\begin{array}{l}\text { Good } \\
\text { f (\%) }\end{array}$ & $\begin{array}{l}\text { Less } \\
\text { f (\%) }\end{array}$ & $\begin{array}{c}\mathbf{p} \\
\text { value }\end{array}$ \\
\hline Sex & & & 0.907 & & & 0.435 & & & 0.692 \\
\hline Male & 2 (8.7) & $1(4.3)$ & & 2 (8.7) & $1(4.3)$ & & 3 (13.1) & $0(0)$ & \\
\hline Female & $14(60.9)$ & $6(26.1)$ & & $17(73.9)$ & $3(13.1)$ & & $19(82.6)$ & $1(4.3)$ & \\
\hline $\begin{array}{l}\text { Level of } \\
\text { education }\end{array}$ & & & 0.315 & & & 0.899 & & & 0.083 \\
\hline $\begin{array}{l}\text { Under Senior High } \\
\text { School }\end{array}$ & $4(17.4)$ & $3(13.0)$ & & $6(26.1)$ & $1(4.3)$ & & $7(30.4)$ & $0(0)$ & \\
\hline Senior High School & $10(43.5)$ & $2(8.7)$ & & $10(43.5)$ & $2(8.7)$ & & $12(52.2)$ & $0(0)$ & \\
\hline Bachelor & $2(8.7)$ & $2(8.7)$ & & $3(13.1)$ & $1(4.3)$ & & $3(13.1)$ & $1(4.3)$ & \\
\hline Occupational & & & 0.360 & & & 0.619 & & & 0.796 \\
\hline Housewife & $11(47.8)$ & $5(21.7)$ & & $14(60.9)$ & $2(8.7)$ & & $15(65.2)$ & $1(4.3)$ & \\
\hline Private & $3(13.1)$ & $0(0)$ & & $2(8.7)$ & $1(4.3)$ & & $3(13.1)$ & $0(0)$ & \\
\hline Entrepreneur & $2(8.7)$ & $2(8.7)$ & & $3(13.1)$ & $1(4.3)$ & & $4(17.4)$ & $0(0)$ & \\
\hline Relationship & & & 0.470 & & & 0.413 & & & 0.925 \\
\hline Parents & $14(60.9)$ & $6(26.2)$ & & $17(74)$ & $3(13.1)$ & & $19(82.7)$ & $1(4.3)$ & \\
\hline Grandmother & $1(4.3)$ & $1(4.3)$ & & $1(4.3)$ & $1(4.3)$ & & $2(8.7)$ & $0(0)$ & \\
\hline Brother & $1(4.3)$ & $0(0)$ & & $1(4.3)$ & $0(0)$ & & $1(4.3)$ & $0(0)$ & \\
\hline
\end{tabular}

test was conducted two weeks after training and there was no intervention in the form of recall about the materials, but the training equipped caregivers with the module.

The questions that the caregivers found difficult to answer were more about theories, such as the definition of self-care and the bath stages and what is taught during toileting. In the choice of answers, they used words that were less familiar and also ambiguous because they related to caregiver habits. Information will be easy to remember if using the traits or characteristics typical of the stimulus (Bhinetty, 2008). There is no distinctive form of training module, so the parents were less interested to read back on the modules that were being given.

Before the training, over half $(56.5 \%)$ of the caregivers already had a positive attitude and this increased after the training. Parental awareness in guiding children with physical disability and preparing them to be able to engage in activities independently could form a positive attitude in the parents (Dziubanek, et al., 2013).

This is evident from the enthusiasm of caregivers in training indicated by their involvement in following the training process. The response of the training process becomes very important to determine the success in transferring a material so that participants are able to understand, determine their attitude, be responsible in applying it and be able to make someone become more creative (Campbell, 2010 cited in McMahon and Archer, 2010).

Caregivers participated in the training because they saw that the training was very useful for their lives, as illustrated by the questionnaire result where the benefits of the training became the best judgment in that more than half of $(60.9 \%)$ the caregivers responded very good to the benefits of training aspect. In line with Fickert and Ross, (2012), activities that have direct implications on a person are likely to be the reason to join the education program. This indicates the appeal of training because the respondents felt that the training materials were what they needed in daily life to teach children how to take care of themselves. In line with Huebner and Milgrom's research results (2014), the benefits of intervention in their lives became the motivation of parents in joining the training program.

Before training, almost half (43.5\%) of the caregivers' skills were good and, after training, about $95.7 \%$ of the caregivers' skills in teaching self-care to children with physical disability became good. In 
Table 4. Overview of Knowledge Before and After Self-Care Training in Physically Disabled Child's Caregiver $(n=23)$

\begin{tabular}{|c|c|c|c|c|}
\hline \multirow[b]{2}{*}{ Question } & \multicolumn{2}{|c|}{ Before } & \multicolumn{2}{|c|}{ After } \\
\hline & Right & False & Right & False \\
\hline 1. Definition of self-care & $19(82.6)$ & $4(17.4)$ & $7(30.4)$ & $16(69.6)$ \\
\hline 2. Self-care benefits & $19(82.6)$ & $4(17.4)$ & $22(95.7)$ & $1(4.3)$ \\
\hline 3. Factors that do not affect self-care & $11(47.8)$ & $12(52.2)$ & $18(78.3)$ & $5(21.7)$ \\
\hline 4. Factors that affect self-care & $11(47.8)$ & $12(52.2)$ & 17 (73.9) & $6(26.1)$ \\
\hline 5. Understanding the bath & $18(78.3)$ & 5 (21.7) & $20(86.9)$ & $3(13.1)$ \\
\hline 6. Step by step bathing & $7(30.4)$ & $16(69.6)$ & 5 (21.7) & 18 (78.3) \\
\hline 7. Equipment for bathing & $23(100)$ & $0(0)$ & $23(100)$ & $0(0)$ \\
\hline 8. Noticed in bathing activities & $20(86.9)$ & $3(13.1)$ & $21(91.3)$ & $2(8.7)$ \\
\hline 9. Dressing activities & $18(78.3)$ & 5 (21.7) & $21(91.3)$ & $2(8.7)$ \\
\hline 10. Purpose of makeup and dressing & $17(73.9)$ & $6(26.1)$ & $20(86.9)$ & $3(13.1)$ \\
\hline 11. Stages of dating & $14(60.9)$ & $9(39.1)$ & 17 (73.9) & $6(26.1)$ \\
\hline 12. Tools to practice dressing up and dressing & $21(91.3)$ & $2(8.7)$ & $21(91.3)$ & $2(8.7)$ \\
\hline 13. What is taught in defecation/urination & $20(86.9)$ & $3(13.1)$ & $18(78.3)$ & $5(21.7)$ \\
\hline 14. Tool for toileting & $19(82.6)$ & $4(17.4)$ & $17(73.9)$ & $6(26.1)$ \\
\hline 15. Purpose of toileting activities & $19(82.6)$ & 4 (17.4) & $20(86.9)$ & $3(13.1)$ \\
\hline 16. Purpose of eating & $10(43.5)$ & $13(56.5)$ & $17(73.9)$ & $6(26.1)$ \\
\hline 17. What a nanny should not do when the child eats & $15(65.2)$ & $8(34.8)$ & $18(78.3)$ & $5(21.7)$ \\
\hline 18. What to consider when eating & $22(95.7)$ & $1(4.3)$ & $20(86.9)$ & $3(13.1)$ \\
\hline
\end{tabular}

Table 5. Overview of Attitude Before and After Self-Care Training in a Physically Disabled Child's Caregiver $\underline{(n=23)}$

\begin{tabular}{|c|c|c|c|c|}
\hline \multirow[b]{2}{*}{ Attitudes Statement } & \multicolumn{2}{|c|}{ Before } & \multicolumn{2}{|c|}{ After } \\
\hline & $\begin{array}{l}\text { Agree } \\
\mathrm{f}(\%)\end{array}$ & $\begin{array}{l}\text { Disagree } \\
\mathrm{f}(\%)\end{array}$ & $\begin{array}{l}\text { Agree } \\
\mathrm{f}(\%)\end{array}$ & $\begin{array}{l}\text { Disagree } \\
\mathrm{f}(\%)\end{array}$ \\
\hline 1. Help the child bathe with wipes & $3(13.1)$ & $20(86.9)$ & $9(39.1)$ & $14(60.9)$ \\
\hline 2. Bathing with water does not use soap & $2(8.7)$ & $21(91.3)$ & $2(8.7)$ & $21(91.3)$ \\
\hline 3. Dry the body with a towel after bathing & $11(47.8)$ & $12(52.2)$ & $7(30.4)$ & $16(69.6)$ \\
\hline 4. Bathing with running water & $22(95.7)$ & $1(4.3)$ & $23(100)$ & $0(0)$ \\
\hline 5. Using soap in all parts of the body & $19(82.6)$ & $4(17.4)$ & $23(100)$ & $0(0)$ \\
\hline 6. Introduce the front and back of the shirt & $23(100)$ & $0(0)$ & $23(100)$ & $0(0)$ \\
\hline 7. Involve children in dress & $7(30.4)$ & $16(69.6)$ & $2(8.7)$ & $21(91.3)$ \\
\hline 8. Praise the child if you can & $19(82.6)$ & $4(17.4)$ & $23(100)$ & $0(0)$ \\
\hline 9. Give opportunity to choose clothes & $21(91.3)$ & $2(8.7)$ & $23(100)$ & $0(0)$ \\
\hline $\begin{array}{l}\text { 10. Teach finding the way to the bathroom if they want } \\
\text { to defecate/urinate }\end{array}$ & $21(91.3)$ & $2(8.7)$ & $23(100)$ & $0(0)$ \\
\hline $\begin{array}{l}\text { 11. Teach hand washing with soap after } \\
\text { defecation/urination }\end{array}$ & $20(86.9)$ & $3(13.1)$ & $23(100)$ & $0(0)$ \\
\hline 12. Tell others when they want defecation/urination & $7(30.4)$ & $16(69.6)$ & $6(26.1)$ & $17(73.9)$ \\
\hline 13. Teach your child how to make a bath & $2(8.7)$ & $21(91.3)$ & $2(8.7)$ & $21(91.3)$ \\
\hline $\begin{array}{l}\text { 14. Teach opening and closing clothes during } \\
\text { defecation/urination }\end{array}$ & $21(91.3)$ & $2(8.7)$ & $22(95.7)$ & $1(4.3)$ \\
\hline 15. Hold the spoon and try other ways to eat & $20(86.9)$ & $3(13.1)$ & $23(100)$ & $0(0)$ \\
\hline 16. Provide light cutlery during exercise & $20(86.9)$ & $3(13.1)$ & $23(100)$ & $0(0)$ \\
\hline 17. Teach children to drink with a straw & $4(17.4)$ & $19(82.6)$ & $4(17.4)$ & $19(82.6)$ \\
\hline 18. Cleaning the mouth before the child finishes eating & $11(47.8)$ & $12(52.2)$ & $6(26.1)$ & $17(73.9)$ \\
\hline 19. Provide special tables and chairs for children & $10(43.5)$ & $13(56.5)$ & $10(43.5)$ & $13(56.5)$ \\
\hline 20. Teach to chew food before swallowing & $22(95.7)$ & $1(4.3)$ & $23(100)$ & $0(0)$ \\
\hline
\end{tabular}

caring for children, mothers have more ability than the father. The mother's ability to provide support and action on the development of children is better. Mothers simply use their experience and cultural values in caring for the child (Unicef, 2014). Mother dominates in this study and the increase of skill to become good is because most of the respondents are mothers (78.26\%).

The parenting skills that changed considerably after the training were in the activities of teaching to regulate the temperature of the water, cleaning the closet, putting clothes in the closet, buttoning clothes, zipper closing, wearing socks, wearing shoes and tidying clothes. After training, all self-care activities were taught to children with physical disability.

The challenge of physically disabled children in dressing activities is how they manage positions to perform these activities. Difficulties that are often experienced include wearing underwear, wearing socks and shoes. The clothes difficult for children with a physical disability to wear are skirts, underwear and uniforms (Kabel, et al., 2017).

Kling, et al. (2010) showed the most difficult routine for children with a physical disability is bathtime. Based on information, parents still find difficulty to find a washing tool for the child's hair, 
Table 6. Descriptions of Before and After Skills Self-Care Training of a Physically Disabled Child's Caregiver $(n=23)$

\begin{tabular}{|c|c|c|c|c|}
\hline \multirow[b]{2}{*}{ Educational Skills Items in.. } & \multicolumn{2}{|c|}{ Before } & \multicolumn{2}{|c|}{ After } \\
\hline & $\begin{array}{l}\text { Done } \\
\mathrm{f}(\%)\end{array}$ & $\begin{array}{c}\text { No } \\
\mathrm{f}(\%)\end{array}$ & $\begin{array}{l}\text { Done } \\
\mathrm{f}(\%)\end{array}$ & $\begin{array}{c}\text { No } \\
\mathrm{f}(\%)\end{array}$ \\
\hline 1. In the bathroom & $19(82.6)$ & $4(17.4)$ & $22(95.7)$ & $1(4.3)$ \\
\hline 2. Take a shower & $20(86.9)$ & $3(13.1)$ & $22(95.7)$ & $1(4.3)$ \\
\hline 3. Preparing water & $14(60.9)$ & $9(39.1)$ & $18(78.3)$ & $5(21.7)$ \\
\hline 4. Adjust the water temperature & $10(43.5)$ & $13(56.5)$ & $16(69.6)$ & $7(30.4)$ \\
\hline 5. Adjust the flow of water & $17(73.9)$ & $6(26.1)$ & $18(78.3)$ & $5(21.7)$ \\
\hline 6. Cleaning all body parts & $19(82.6)$ & $4(17.4)$ & $22(95.7)$ & $1(4.3)$ \\
\hline 7. Dry the body after bathing & $21(91.3)$ & $2(8.6)$ & $23(100)$ & $0(0)$ \\
\hline 8. Exit the bathroom & $17(73.9)$ & $6(26.1)$ & $21(91.3)$ & $2(8.6)$ \\
\hline 9. In the bathroom when you want BAB / BAK & $18(78.3)$ & $5(21.7)$ & $21(91.3)$ & $2(8.6)$ \\
\hline 10. Uncover the underwear & $17(73.9)$ & $6(26.1)$ & $23(100)$ & $0(0)$ \\
\hline 11. Positioning yourself in the toilet & $19(82.6)$ & $4(17.4)$ & $21(91.3)$ & $2(8.6)$ \\
\hline 12. Cleaning yourself after the BAK & $19(82.6)$ & $4(17.4)$ & $23(100)$ & $0(0)$ \\
\hline 13. Cleaning after BAB & $17(73.9)$ & $6(26.1)$ & $22(95.7)$ & $1(4.3)$ \\
\hline 14. Clean the closet & $11(47.8)$ & $12(52.2)$ & $18(78.3)$ & 5 (21.7) \\
\hline 15. Make clothes after BAB / BAK & $17(73.9)$ & $6(26.1)$ & $22(95.7)$ & $1(4.3)$ \\
\hline 16. Exit the bathroom & $18(78.3)$ & $5(21.7)$ & $23(100)$ & $0(0)$ \\
\hline 17. Wash hands after BAB / BAK & $19(82.6)$ & $4(17.4)$ & $23(100)$ & $0(0)$ \\
\hline 18. Preparing food & $15(65.2)$ & $8(34.8)$ & $17(73.9)$ & $6(26.1)$ \\
\hline 19. Open the food cover & $15(65.2)$ & $8(34.8)$ & $17(73.9)$ & $6(26.1)$ \\
\hline 20. Using cutlery (plates, spoons, forks) & $22(95.7)$ & $1(4.3)$ & $22(95.7)$ & $1(4.3)$ \\
\hline 21. Put food in cutlery & $17(73.9)$ & $6(26.1)$ & $20(86.9)$ & $3(13.1)$ \\
\hline 22. Put food into the mouth & $21(91.3)$ & $2(86)$ & $23(100)$ & $0(0)$ \\
\hline 23. Chew food & $21(91.3)$ & $2(8.6)$ & $22(95.7)$ & $1(4.3)$ \\
\hline 24. Swallowing food & $21(91.3)$ & $2(8.6)$ & $22(95.7)$ & $1(4.3)$ \\
\hline 25. Spend the food & $19(82.6)$ & $4(17.4)$ & $22(95.7)$ & $1(4.3)$ \\
\hline 26. Hold and drink from a cup & $22(95.7)$ & $1(4.3)$ & $23(100)$ & $0(0)$ \\
\hline 27. Choosing clothes & $15(65.2)$ & $8(34.8)$ & $14(60.9)$ & $9(39.1)$ \\
\hline 28. Take the clothes from the closet & $13(56.5)$ & $10(43.5)$ & $15(65.2)$ & $8(34.8)$ \\
\hline 29. Wear upper garment & $14(60.9)$ & $9(39.1)$ & $23(100)$ & $0(0)$ \\
\hline 30. Buttoning clothes & $10(43.5)$ & $13(56.5)$ & $15(65.3)$ & $8(34.8)$ \\
\hline 31. Wear underwear & $14(60.9)$ & $9(39.1)$ & $22(95.7)$ & $1(4.3)$ \\
\hline 32. Closing the zipper & $12(52.2)$ & $11(47.8)$ & $17(73.9)$ & $6(26.1)$ \\
\hline 33. Wear socks & $11(47.8)$ & $12(52.2)$ & $20(86.9)$ & $3(13.1)$ \\
\hline 34. Wear shoes & $12(52.2)$ & $11(47.8)$ & $18(78.3)$ & $5(21.7)$ \\
\hline 35. Tidy clothes & $13(56.5)$ & $10(43.5)$ & $20(86.9)$ & $3(13.1)$ \\
\hline 36. Take off the upper shirt & $19(82.6)$ & $4(17.4)$ & $21(91.3)$ & $2(8.6)$ \\
\hline 37. Unfold underwear & $17(73.9)$ & $6(26.1)$ & $22(95.7)$ & $1(4.3)$ \\
\hline
\end{tabular}

vibrating toothbrush, and a special chair to change the position of the body when the child is in the bathroom.

Difficulties often experienced in toileting activities by children with physical disability is the difficulty of moving and positioning themselves in the closet, needing a special seat for them to move. The difficulties that are often experienced by children having incontinence are in opening underwear before toileting, difficulty in cleaning after toileting and difficulty closing zippers (Noble, 2014).

Self-care training for caregivers of children with physical disability does not have a significant effect on knowledge where the $\mathrm{p}$ value is 0.225 . It can be seen from the mean value, that there less significant increase from before and after training, i.e. 13.17 to 14.00 , where the difference test shows a difference mean of 0.826 with value t count 1.249 , smaller than t table, 2.0739, which means that the training does not have a significant influence on knowledge.

Less knowledge is increased due to the giving of materials done in the classroom where the information is given by the trainer to some people in front of the class. According to Vahdaniya, et al. (2015), giving the material in the class is less likely to increase knowledge compared with telling stories.

The study of the instruments of knowledge assessment has become a concern as a result of caregiver knowledge being insignificant. According to Nunally (1978 cited in Widhiarso, 2005), instruments that have a reliability value $<0.7$ are less adequate as a measuring tool. In this research, the reliability of the knowledge instrument questionnaire is 0.673 , which means that the instrument is less consistent to be used as a measuring tool; this happens because it is difficult to find the subjects for a validity and reliability test. Testing the validity of reliability was only followed by 34 people out of 30 question items with only 18 valid questions. Of the 18 questions, there were three $(16.7 \%)$ questions that experienced a decrease in mean value after self-care training, namely, the question of the definition of self-care, bath steps and toileting tools. There was one question 
Table 7. Caregiver Response to the Training on Caring for a Physically Disabled Child March-April 2017 $(\mathrm{n}=23)$

\begin{tabular}{lcccccc}
\hline \multirow{2}{*}{ No. Item } & \multicolumn{5}{c}{$\mathrm{f}(\%)$} & Total \\
\cline { 2 - 6 } & $\begin{array}{l}\text { Very } \\
\text { Less }\end{array}$ & Less & Sufficient & Good & Very Good \\
\hline Preparation & $0(0)$ & $0(0)$ & $0(0)$ & $11(47.8)$ & $12(52.2)$ & $23(100)$ \\
\hline Training Facilities & $0(0)$ & $0(0)$ & $1(4.3)$ & $18(78.3)$ & $4(17.4)$ & $23(100)$ \\
\hline Training Materials & $0(0)$ & $0(0)$ & $1(4.3)$ & $10(43.5)$ & $12(52.2)$ & $23(100)$ \\
\hline Training Media & $0(0)$ & $0(0)$ & $1(4.3)$ & $12(52.2)$ & $10(43.5)$ & $23(100)$ \\
\hline Trainer & $0(0)$ & $0(0)$ & $1(4.3)$ & $14(60.9)$ & $8(34.8)$ & $23(100)$ \\
\hline Training Benefits & $0(0)$ & $0(0)$ & $0(0)$ & $9(39.1)$ & $14(60.9)$ & $23(100)$ \\
\hline Training Time & $0(0)$ & $0(0)$ & $3(13.1)$ & $18(78.3)$ & $2(8.7)$ & $23(100)$ \\
\hline
\end{tabular}

Table 8. Effects of Self-Care Training on Knowledge, Attitudes and Skills of Caregivers Regarding the Care of a Physically Disabled Child ( $\mathrm{n}=23)$

\begin{tabular}{|c|c|c|c|c|c|}
\hline Outcomes & Min & Max & Mean (SD) & t (df) & p Value \\
\hline Knowledge & & & & & 0.225 \\
\hline Pretest & 9 & 18 & $13.17(2.443)$ & & \\
\hline Posttest & 8 & 17 & $14.00(2.195) 0.826$ & & \\
\hline Pretest-Posttest & & & $(3.172)$ & 1.249 (22) & \\
\hline Attitudes & & & & & $0.038^{*}$ \\
\hline Pretest & 37 & 71 & $59.57(6.451)$ & & \\
\hline Posttest & 56 & 68 & $62.61(3.905) 3.043$ & & \\
\hline Pretest-Posttest & & & (6.595) & $2.213(22)$ & \\
\hline Skills & & & & & $0.002^{*}$ \\
\hline Pretest & 4 & 37 & $26.74(7.794)$ & & \\
\hline Posttest & 26 & 37 & 33.17 (3.537) 6.435 & & \\
\hline Pretest-Posttest & & & (8.659) & $3.564(22)$ & \\
\hline
\end{tabular}

T table value with $\mathrm{df}(22)=2.0739$ with significance level $95 \%$

that did not change after the training, which was about equipment for bathing.

Self-care training improves the attitude of caregivers for children with physical disability. Based on the result of the paired sample t test, $p$ value of 0.038 and $t$ value 2.213 were greater than $t$ table; this means self-care training had an effect on the attitude of the caregivers. In the Kling, et al. (2010) study, after training on supportive technology for children with physical disability, there was increase in attitude of caregivers and they were able to choose a solution to their problem with the appropriate support tools.

After the training, caregivers' skills increased significantly based on the results of the paired sample $t$ test and obtained p 0.002, which means the skills of parents were better after the training. Training can improve parenting skills more compared to those who only seek information from the literature (Kling, et al., 2010).

The success of the training in this study is based on the evaluation obtained from the caregivers, as it assessed for both the media training (52.2\%), speaker $(60.9 \%)$ and time and training facilities $(78.3 \%)$. The improvement of caregiver skills was supported by an audiovisual learning media where parents were given the opportunity to see videos on how to teach children with physical disabilities. In addition, caregivers were given the opportunity to practice firsthand the materials that had been given by involving the child in the training activities of bathing, toileting, eating and dressing.

In a study conducted by Lehna, et al. (2013), which aimed to compare educational methods of classroom meetings, DVDs, home visits, leaflets, telephone contacts, pamphlets, and short messages on research subjects with parents with physically disabled children, visual disturbances and control groups showed the most effective method of education on such parent groups is classroom meetings, DVDs and home visits. Based on the theory of learning outcome, training is effective in improving skills. According to Bandura (1971), a person's behavior is formed from the process of observation (attentional phase), retention phase, reproduction phase and motivation to do something (motivation phase). The phases are done by parents in the training process where they observe through audiovisual and demonstration, being given the material, imitating through practice activities and then practice at home.

\section{CONCLUSION}

Almost half the knowledge before self-care training was good and, after training, the majority became good. More than half of the caregivers had a positive attitude before training and this improved to almost all after training. Self-care training for caregivers of children with physical disability could improve their attitude and skills, but did not affect their knowledge.

This study had a limited number of respondents. In future research, a greater number of respondents could be used as a more valid reference source. Better caregivers are always looking for an adequate source of information on how to help children in self-care activities. Providing facilities that enable children to run self-care activities, always give the opportunity and enables the child to perform self-care activities independently. 
Health services need to pay attention to the right media in providing education, and shape the purpose according to the needs of the audience. Work with schools should include self-care training curriculum programs involving physical disability caregivers. Work should be done with stakeholders to provide facilities that help children with a physical disability to meet self-care needs, such as bathing, toileting, cutlery, dressing and dressing facilities that are easy to use for them.

Further research using more valid and reliable research instruments should be undertaken. There should be development of skills assessment tools that fit the child's physical disability-related disability. Observations need to be made on the appropriate schedule according to the child's activities.

\section{REFERENCES}

Aizpurua, A., Bajos, A.G. and Migueles, M. (2009). False Memories for a Robbery in Young and Older Adults. Applied Cognitive Psychology, 23, pp. 174187. DOI: $10.1002 /$ acp.1461.

Barbotte, E.G. and Chau. F, (2011). Prevalence of Impairments, Disabilities, Handicaps and Quality of Life in the General Population: A Review of Recent Literature. Bulletin of the World Health Organization, 79 (11), p. 1047.

Bhinnety, M. 2008. Struktur dan proses memori. Buletin Psikologi, 16 (2), pp. 74-88. Universitas Gadjah Mada.

Chung, J., Evans, J., Lee, C., Lee, J., Rabbani, Y. and Roxborough, L. (2008). Effectiveness of adaptive seating on sitting posture and postural control in children with cerebral palsy. Pediatric Physical Therapy, 20, pp. 303-317. http://dx.doi.org/10.1097/PEP.0b013e31818b7 bdd.

Dziubanek, G., Marchwinska, W.E., Piekut, A., Hajok, I., Bilewicz, W.T. and Kuraszewska, B. (2013). Environmental risk perception-a study of the awareness of families to threats in areas with increased health disorders in children. Annals of Agricultural and Environmental Medicine, 20(3), pp. 555-558.

Fickert, N.A. and Ross, D. (2012). Effectiveness of a Caregiver Education Program on Providing Oral Care to Individuals with Intellectual and Development Disabilities. Intellectual and Developmental Disabilities, 50(3), pp. 219-232. DOI: 10.1352/1934-9556-50.3.219.

Heubner, C.E. and Milgrom, P. (2014). Evaluation of a parent-designed programme to support tooth brushing of infants and young children. International Journal of Dental Hygiene. DOI:10.1111/idh.12100

Kabel, A., Dimka, J. and Black, K.M. (2017). Clothingrelated barriers experienced by people with mobility disabilities and impairments. Applied Ergonomics, 59, pp. 165-169. http://dx.doi.org/10.1016/j.apergo.2016.08.036.

Kling, A., Campbell, P.A. and Wilcox, J. (2010). Young Children With Physical Disabilities Caregiver Perspectives About Assistive Technology. Infant \& Young Children. Wolters Kluwer Health. Lippincott Williams \& Wilkins, 23(3), pp. 169-183.

Lehna, C., Janes, E.G., Rengers, S., Graviss, J., Scrivener, S.D., Knabel, S.T. and Myers, J.A. (2013). Impact of Children with Special Needs on Differences in Fire-Safety Education Priorities, Preferred Method of Education, and Parent Actions. Journal of Burn Care \& Research. DOI: 10.1097/BCR.0b013e31828a480a.

McMahon, G. and Archer, A. (2010). 101 Coaching Strategies and Techniques. London and New York: Routledge Taylor \& Francis Group.

Noble, E. (2014). Using Prompts to Improve Toilet Training for Children with Physical Disabilities. [online] Available at: https://cdnrifton.azureedge.net/-/media/files/rifton/whitepapers/toilet-training-children-physicaldisabilities.pdf?la=en (Accessed: April 27, 2017).

Notoatmodjo. (1993). Pengantar Pendidikan Kesehatan dan Ilmu Perilaku Kesehatan. Andi Offset. Yogyakarta.

Riset Kesehatan Dasar (Riskesdas). 2013. Badan Penelitian dan Pengembangan Kesehatan Kementerian RI tahun [online] Available at: http://www.depkes.go.id/resources/download/ general/Hasil\%20Riskesdas\%202013.pdf (Accessed: April 27, 2017).

Tristani, L.K., Gunter, R.B. and Tanna, S. (2017). Evaluating Internet-Based Information on Physical Activity for Children and Youth With Physical Disabilities. Adapted Physical Activity Quarterly, 34, pp.55-71. https://doi.org/10.1123/APAQ.2016-0012.

Unicef. (2014). Study of Parental Knowledge, Attitudes, and Practice Related to Early Childhood Development. [online] Available at: https://www.unicef.org/pacificislands/ECD_KAP _Solomon_Islands.pdf (Accessed: April 27, 2017).

Vahdaninya, Z., Nakhaei, M., Nasiri, A. and Sharifzadeh, G. 2015. Training based on Orem's model on knowledge, attitude and self-efficacy of mothers in preventing domestic accidents. Modern Care Journal, 12(3), pp.119-124.

WHO. (2015). Health Education. [online] Available at: http://www.who.int/topics/health_education/en / (Accessed: April 27, 2017).

Widhiarso, W. (2005). Mengestimasi Reliabelitas. Fakultas Psikologi UGM. Yogyakarta.

YPAC. 2016. Laporan Akademik Tahun Surakarta: Yayasan Pembinaan Anak Cacat. 